\title{
Social dialogue, workers' rights and freedom of association in the western Balkans - a survey after a first round of empirical research
}

\begin{abstract}
This article presents a survey conducted on behalf of the Friedrich Ebert Foundation into the causes of the decline of trade unions and of their potential in the western Balkans. The survey stems from a major concern that the social challenges of the transformation have led people to be more in need of a trade union than ever before but that the loss of the obligation to be a union member and the switch in the role of the union from that which applied before the transition have led to membership trends and union activities not keeping pace with what would seem to be required. The study explores as causes the institutional structure, trade union capacity and workplace representation, collective bargaining practice and coverage, the right to strike, the role of minimum wages, the state of the social dialogue and the record of implementation on employee and trade union rights. It concludes that trade union organisations are in no place to meet these challenges on their own and, therefore, that avenues for social dialogue projects within the structure of European pre-accession support funds need to be explored.
\end{abstract}

Keywords: trade unions, transformation, EU accession, social dialogue, workplace representation, works councils, collective bargaining, minimum wage, right to strike, enforcement, EU pre-accession funds

\section{Introduction}

For almost two decades, the ten new EU member states in eastern Europe, and also the current and future accession candidates in the western Balkans, have been going through a process of transformation which has had far-reaching consequences. In some of these countries, the process appears to be virtually complete and they have either already joined, or are about to join, the euro zone. The process of transformation is making huge demands on the political and social players in these countries in terms of the social adjustment to a market economy, privatisation, workforce cuts, unemployment and the ongoing process of integrating into the EU. And this is without taking into account the impact of the current global economic crisis.

At the same time, trade unions in eastern Europe are suffering an unmistakable process of the erosion of their membership and status (see Figure 1). Removal of the former obligation to join a union has reduced subscription income and the resources that trade union leaders require in order to meet the demand for greater professionalism in their advisory role. However, the social challenges of transformation mean that, more than ever before, employees need the collective support of strong trade unions. That 
interest in joining a union and the realisation of the extended employee rights offered by new legislation have not kept pace with these challenges clearly has deep-rooted causes.

\section{Figure 1 - Loss of trade union membership in eastern and western Europe, 1995-2008}

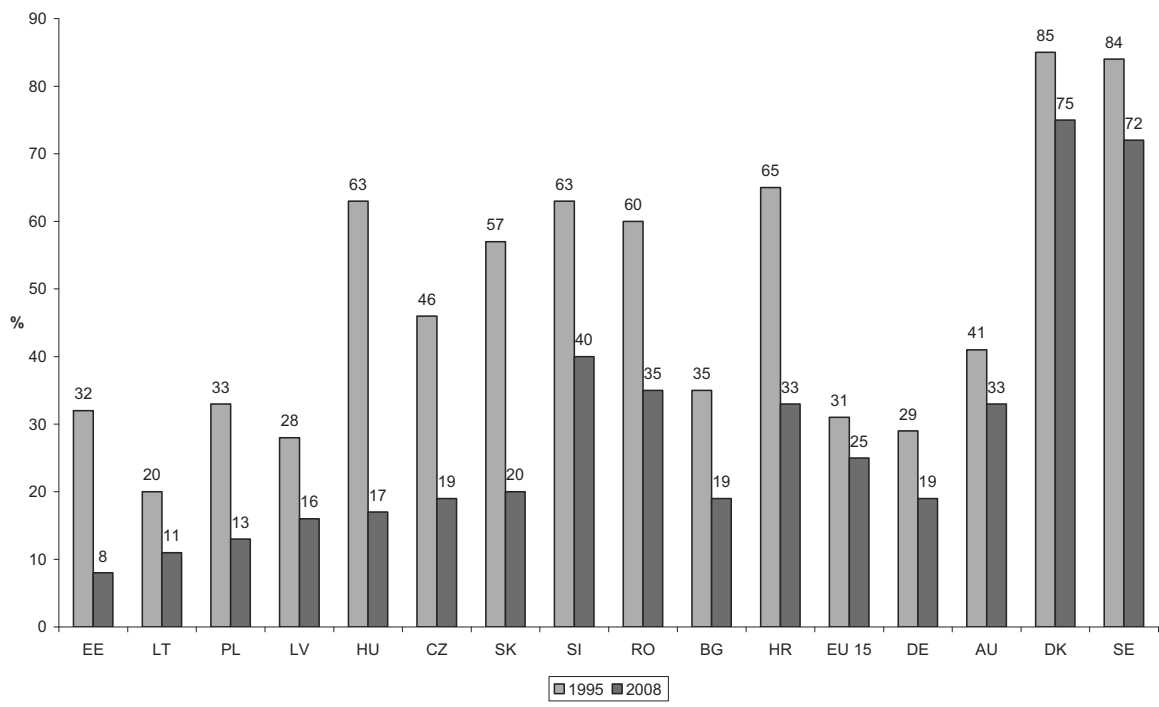

On the basis of their years of activity at the local level, the representatives of the German Friedrich Ebert Foundation responsible for trade union co-operation in eastern Europe felt an obligation to carry out a special analysis to identify these causes. The project study was triggered by the realisation on the part of Clemens Rode, the regional co-ordinator in Warsaw, that:

It is not just hostility on the part of managers and companies that explains the low levels of trade union membership - there are also other obstacles, including legal ones, which hinder people from joining trade unions. In Poland, for example, there has to be a minimum of ten employees in a particular company for it to be possible to register a trade union with the courts. The concept of joining via a sectoral trade union does not exist.

Detailed responses were forthcoming from all the countries concerned and formed an important basis for the present analysis. In parallel to this, Frank Hantke, Belgrade regional co-ordinator for the Friedrich Ebert Foundation, also took up the idea of the project but adopted a slightly different approach. Experts from the six countries of the western Balkans - including Albania as well as the successor states of Yugoslavia were commissioned to draw up detailed reports on the current situation regarding freedom of association and social dialogue. These were then used as a basis for in-depth discussion during special workshops in all six capital cities involving representatives 
of trade unions, employer associations and the labour ministries. As regards Kosovo, only an initial approach via interviews and research conducted with actors in the social dialogue could be facilitated for this purpose within the structure of an ongoing EU project on 'Social Dialogue in Western Balkan countries'. Here, it must be borne in mind that the Republic of Kosovo is a young state (proclaimed February 2008) with still many gaps in its legal, political and administrative structures.

\section{Preconditions of social dialogue in the western Balkans}

At the first round of EU enlargement in 2004 and 2007, ten former socialist countries joined the Union, half of them only just having gained national sovereignty in the previous process of transition after 1990. Six of the seven countries of the western Balkans that will be taking part in the next round of EU accession are former republics (or, in the case of Kosovo, an autonomous region) of Yugoslavia - only Albania existed previously as an independent state. All this has created tremendous challenges for these societies concerning state building, transition to the market economy via privatisation and job loss, as well as the necessary adoption of the social acquis under the current process of EU accession.

The trade unions in these countries, unlike those in central eastern Europe, did not play any decisive role in the restructuring of society during the period of transition. This was largely due to the transformation in this region bringing the 'national question' to the fore rather than, as elsewhere, the decisive 'social question' or economic concerns. Moreover, the achievement of state sovereignty was accompanied in Croatia and Bosnia by many years of bloody conflict during the civil wars of the early 1990s.

The consequence is that there was a delay in the necessary process of adapting and reshaping industrial relations and labour law. At the same time, the process of uncontrolled privatisation set in at an early stage, with a host of adverse consequences for the workforce. Initially, there were no employer associations, similar to the position in other transition states, which meant that the relevant national tripartite bodies - in the form of economic and social councils, with the participation of the social partners were only established after some delay and which, to this day, have not managed to acquire much political influence.

Conversely, however, this also meant that the notion of pluralism for both sides of industry had noticeably less impact than in north-eastern Europe. Only Croatia saw the establishment of a multitude of new and competing employee confederations at national level while elsewhere, with the exception of Albania, at most one new alternative organisation emerged alongside the traditional trade union federations (Figure 2).

Concerning Kosovo, there is at present a blockade of the social dialogue and, thus, of the further development of industrial relations. The bottleneck here is obviously the necessary acceptance of organisational pluralism on the employer side as much as on the trade union side. The recently-established tripartite Socio-Economic Council is to be enlarged by another trade union confederation (KSLK) and by the Business Association of Kosova, both of which fulfil the representativeness criteria set by the government although this is contested by the Chamber of Commerce and also by the trade union confederation, BSPK. Thus, urgent topics such as the introduction of a comprehensive labour code and the setting of the minimum wage for 2010 cannot be transferred 
to the wider political decision-making process. Nor is a resolution to the important question of the pending implementation of the national tripartite collective agreement (from 2004), necessarily based on a labour code, possible at this moment in Kosovo.

\section{Figure 2 - Representative trade union and employer umbrella organisations ${ }^{1}$}

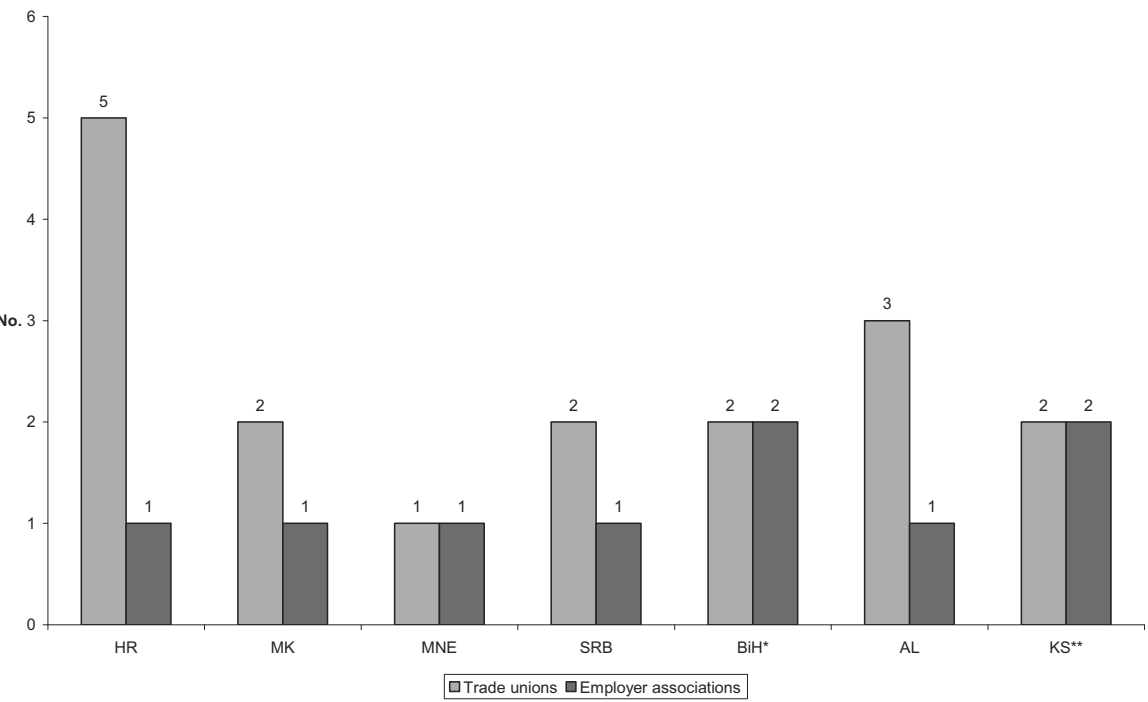

* including Republika Srpska

** the Chamber of Commerce as well as the Business Association of Kosovo represent employers

Croatia and Macedonia (as referred to hereafter, rather than the official EU compromise term Former Yugoslav Republic of Macedonia, or FYROM) have been candidates for EU enlargement for some time. As such they are subject to regular EU screening procedures and are integrated into the Eurostat reporting system, so there is more data available for these countries than for the other four states covered by this study, i.e. Bosnia-Herzegovina (BiH), Montenegro, Serbia and Albania.

Croatia, however, is a country which, in contrast to Macedonia, is likely to accede in the shorter term (a decision on accession is due in the coming year, with 2011 or 2012 hitherto envisaged as the possible date of accession). It has also already adapted its fundamental structures more completely to the European social model, as highlighted in the EU Progress Report on the region for 2008 and again in October 2009.

It should be pointed out that the state structure of Bosnia-Herzegovina was defined in the Dayton Agreement of 1995 as the conjoining of two independent administrative

1 Country abbreviations: $\mathrm{HR}=$ Croatia; $\mathrm{MK}=$ Macedonia; $\mathrm{MNE}=$ Montenegro; $\mathrm{SRB}=$ Serbia; $\mathrm{BiH}=$ Bosnia and Hercegovina; $\mathrm{AL}=$ Albania; $\mathrm{KS}=$ Kosovo; $\mathrm{RS}=$ Republika Srpska (a discrete 'entity' within Bosnia-Herzegovina, largely with its own legislation and administration). 
units ('entities'), i.e. the Bosniak-Croat Federation and Republika Srpska, with its capital at Banja Luka). Each entity has its own legislation - including labour law - and administrative structures. Consequently, each half of the state has an autonomous association of employees and of employers but no uniform representation of the social partners (cf. Appendix).

All seven countries are relatively small states, ranging from a population of 630000 (in Montenegro) to 4.4 million (in Croatia) and to some 7 million in Serbia. Relative to their size, individual countries often appear to have an excessively large number of sectoral trade unions as member associations of the national confederations, particularly in Croatia (see Figure 3). This invariably raises the question of the power of the sectoral associations and how much real influence they have.

\section{Figure 3 - Number of sectoral trade unions in south-eastern Europe}

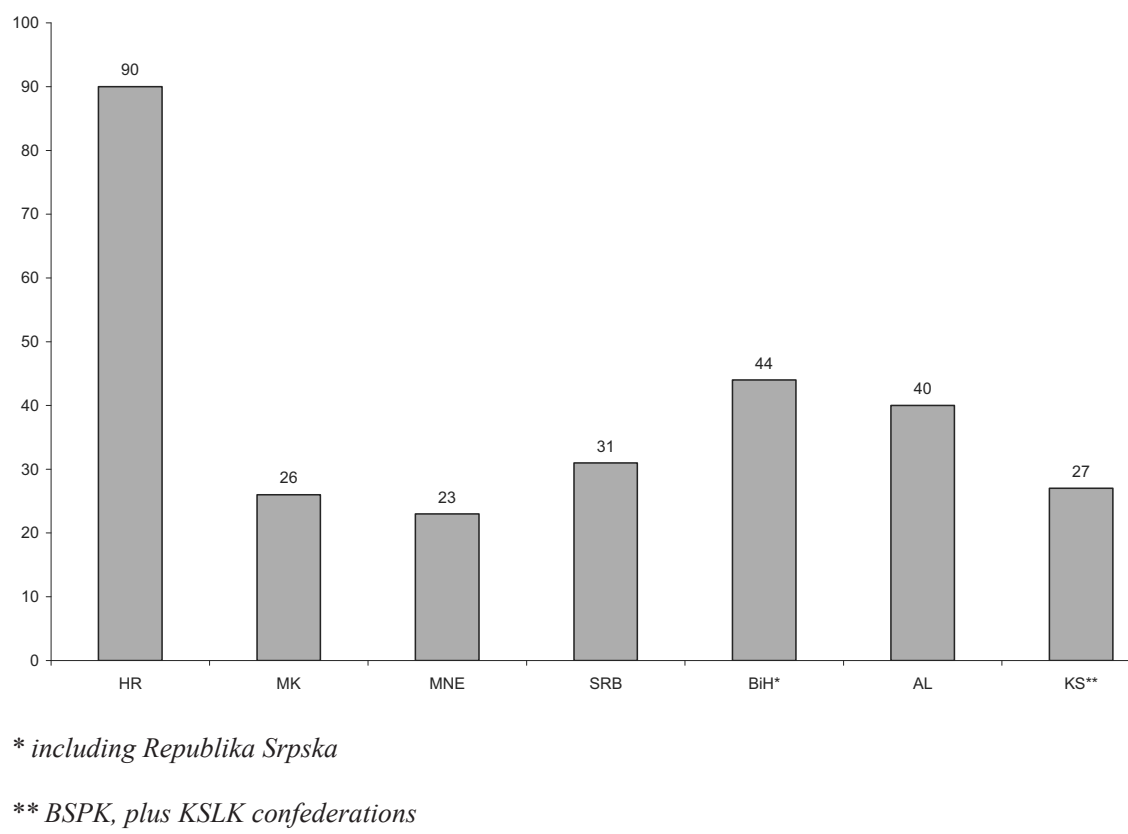

At the same time, union density in all of the countries has fallen considerably - by over half compared with 1990 - albeit not as drastically as in many other post-socialist countries of eastern Europe (see Figure 1 and Table 1).

Table 1 - Union density in trade union confederations in south-eastern Europe (\% of all employees)

\begin{tabular}{|c|c|c|c|c|c|c|}
\hline HR & MK & MNE & SRB & BiH & AL & KS \\
\hline 35 & 30 & 35 & 33 & 30 & 23 & $20-25$ \\
\hline
\end{tabular}


When considering this data, it should be borne in mind that, to a large extent, these are figures or estimates from the relevant organisations themselves. Furthermore, $\mathrm{BiH}$, Macedonia and Albania have unemployment rates of over $30 \%$ and, at the same time, a high proportion of informal employment, which makes the situation even more complex. In Kosovo, only a minority of members pays regular trade union fees - partly due to an extremely high proportion of unemployment (see below, Table 2).

\section{Capacity building of trade union organisations}

A small membership always creates problems with regard to the financial and personal resources of an organisation. Apart from the number of members, the main problem is how funding is obtained and spent. On the one hand, there is the usual requirement under union statutes to pay membership subscriptions, amounting to $1 \%$ of individual gross income. However, honesty is called for, especially where membership subscriptions are set according to the minimum wage. Current practice only serves to exacerbate this situation, since an employer will deduct union membership subscriptions directly from pay, but pay may officially consist of only the minimum wage (supplemented by an undeclared amount of cash in hand). A further difficulty is that not all members, by a long way, can afford to pay membership subscriptions. In Albania, for instance, it is reported that only $25-30 \%$ of members pay any subscription at all, let alone the subscription laid down in the statutes. In addition, a considerable part of members are pensioners.

Membership subscriptions are collected by the employer - who can thus exercise complete control over union members in the company. Subscriptions are then passed on directly to company trade union representatives who, under union statutes, can use between $60 \%$ and, in extreme circumstances, up to $90 \%$ of the funds for their own purposes. The remaining income from membership subscriptions must be shared between the sectoral association and the umbrella organisation (in Serbia, the latter receives around $5 \%$ ). This means that a sectoral organisation has, on average, a mere $10-15 \%$ of membership income at its disposal - too little for financing the running costs of the organisation along with campaigns, activities or the necessary expert personnel, not to mention amassing a strike fund for use in the event of a serious industrial dispute. The consequence has been that umbrella organisations continue to have limited scope and a decentralised structure, based primarily at company or site level, continues to predominate.

Even where the method of distributing membership income is more favourable for umbrella organisations - as in Montenegro and Macedonia, with shares of between $20 \%$ and $30 \%$ - this does not necessarily mean that these high-level organisations are better funded, given the relatively small populations and low employment rates in these countries.

It is true that, as a rule, the countries of the western Balkans have no specific legislation governing the organisation of trade unions or employer associations - in contrast to eastern Europe - but the thresholds for recognition as a representative organisation are nonetheless set high. This is necessary to legitimise both collective bargaining and participation in tripartite national economic and social councils. For employer associations, this threshold ranges between at least $10 \%$ and $25 \%$ of all relevant em- 
ployees in their member companies, on the basis of which they are considered representative and thus entitled to participate in tripartite bodies.

The threshold for trade union recognition for collective bargaining is, in some cases, considerably higher: in Serbia, the requirement is a minimum membership of $15 \%$; in Bosnia, $20 \%$; in Macedonia, up to $33 \%$; and in Albania, 50 \%. In Croatia, however, the threshold is relatively low and only required as regards participation in the tripartite councils. This explains the large number of five 'representative' trade unions in the country, a state of affairs that meets with strong criticism from the leading confederation, SSSH, which would like to see the much stricter criteria applying to employers applied also to the Croatian trade union confederations. In Kosovo, this hurdle for representativeness is also set comparatively low, at just $10 \%$.

In the western Balkans, the situation between the social partners is somewhat distorted by trade unions being very poorly represented in SMEs, whereas these are the companies from which the employer associations recruit the majority of their members.

In all countries of the region, the establishment of grass roots trade union organisation, at both local and supra-company level, is relatively straightforward from a legal point of view. The minimum number of members required for the establishment of a union in a company ranges from three to ten employees, depending on the relevant labour legislation and the statutes of the organisation. The minimum requirement for establishing a trade union at supra-company level is only slightly higher. A markedly higher prerequisite has to be fulfilled in Kosovo to create local representation, which must be based on more than fifty plus one per cent of the workforce.

The registration procedure that is required once a trade union federation or national confederation has been established can prove to be more problematic in certain cases, since state approval is always necessary. Thus, the umbrella organisation SSSBiH in the Bosniak-Croat Federation is still not legally recognised - a situation stemming from the complex constitutional circumstances in the country.

Individual trade union membership, as an essential component of freedom of association, is subject to some restrictions - similar to those in central eastern European countries - which have an adverse impact on employees in the many small enterprises in particular:

- the principal 'filter' in this respect is, once again, the ubiquitous rule that employees may only join a union via the company trade union representation. In principle, this is the case in Montenegro, Serbia, Bosnia and Albania

- conversely, however, it is also usual to join via a sectoral trade union in Macedonia, or at all levels of an organisation in line with union statutes in Croatia.

The following groups are legally excluded from membership:

- Croatia and Serbia have a provision that stipulates an existing employment relationship as a condition for joining a union. In practice, there are numerous 'exceptions' in Croatia, where this regulation is ignored. Of much more serious import, however, is that almost $90 \%$ of new recruitment is for a fixed term, which prevents many people who are newly entering employment, or changing jobs, from joining a trade union

- in Macedonia, pensioners are banned from membership, as are certain members of the public service and the police 
- in Montenegro, membership amongst those in senior management within state cultural and educational institutions is undesired and, therefore, unusual

- apart from the police, army employees and their relatives were banned from membership in Serbia until 2008. Today, the latter is still true of Bosnia.

In summary, therefore, the legal grounds for exclusion from membership in southeastern Europe are, on the whole, less pronounced than in some new EU member states. However, in south-eastern Europe there is a proliferation of additional obstacles to the genuine exercise of the right to freedom of association.

It is generally true for this region too, that it can be extremely difficult to prove actual discrimination by an employer against trade union members or their elected representatives. Disciplinary action entailing compulsory transfer or dismissal is frequently justified on the grounds of professional misconduct, or similar. In its annual publications on infringements of trade union rights, the ITUC reports on serious cases of harassment and the repression of employees who exercise their legal rights to representation and freedom of association in all these countries (ITUC, 2008 and 2009).

Challenging such violations proves difficult where, as in Serbia, labour law does not provide for sanctions for discrimination against trade unions, which would make effective prosecution easier, or where there is an absolute absence of a comprehensive labour code setting out minimum standards, such as in Kosovo, which weakens the function of the existing Labour Inspectorate. In $\mathrm{BiH}$, too, there are no sanctions for such violations, although trade union officials and the few works councils in the country do benefit from specific legal protection.

Nonetheless, in instances of indirect discrimination in Croatia, the burden of proof falls on the employer, who has to prove that measures taken against active trade unionists are justified on grounds related purely to their work.

A particularly serious violation by the state authorities of the right to freedom of association was reported in Albania in 2007. The two national confederations, KSSH and BSPSH, were expelled by the police from their offices with brute force on the grounds of unresolved property issues linked to their status as successor organisations to the former state-run trade union. Property and documents, etc. were partially destroyed in the raid. To date, neither confederation has been rehabilitated (ITUC, 2008 and 2009). Similarly, it is not always possible to bring effective prosecutions in Albania following illegal pressure placed on company union representatives or the illegal dismissal of trade unionists. The same goes for the establishment of 'yellow' trade unions.

\section{Workplace representation}

This is almost exclusively executed by the local trade union organisation - as far as any exists. The latter is particularly a problem in SMEs and the numerous 'union-free' companies. Despite the long tradition of workers councils under the socialist system of self-management in Yugoslavia, elected employee councils today no longer play any significant role in the countries of the western Balkans with the exception of Croatia. In practice, employee representation has an overwhelmingly uniform structure, generally consisting of company-based trade union representatives. This, however, is again dependent on the level of union density in a company. 
In Croatia, however, a large number of works councils were introduced from 1996 onwards, subsequent to the implementation of the new 1995 Labour Code (Zakon o radu) and are now widespread, primarily in large and medium-sized companies. The structure of these works councils is similar to those in continental Europe, albeit with fewer participation rights.

Figure 4 - High legal barriers to setting up a works council in central and southeast European countries

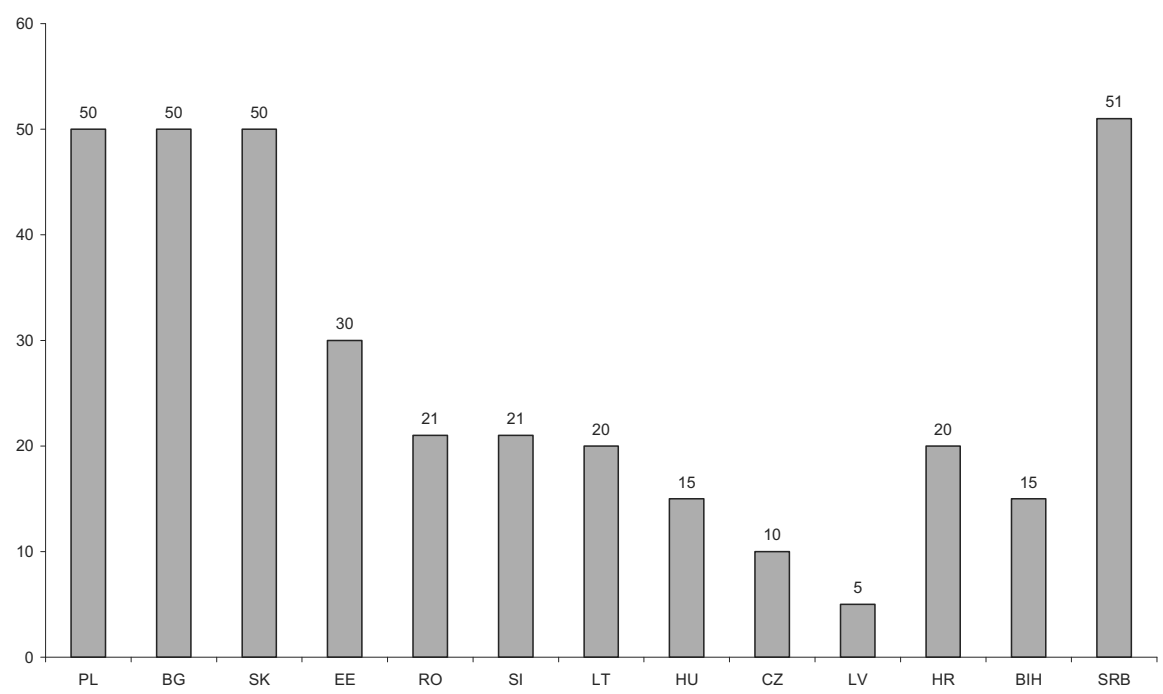

(minimum number of employees for the election of a works council)

Nonetheless, in Bosnia and in Serbia too, legislation since the new millennium has made it legally possible to establish works councils within a dual system consisting of employee representatives elected by the entire workforce operating alongside existing local union representatives (Figure 4). This legislation, however, expressly requires both representative bodies to co-operate with each other and also clearly specifies the distinct competences of each.

In companies without a works council in Croatia and in Bosnia, trade union representatives can exercise the rights to information and consultation that a works council would have, as well as its other statutory participation rights. This means, however, that there is no particular incentive for a trade union to establish a works council in order to obtain more representation in the interests of the workforce. Even so, under the 1999 Labour Law in the Bosniak-Croat Federation, a works council is required to give an opinion on all cases of dismissal in that company and, in the event of the dismissal of an employee with a disability, for example, it is even asked for formal consent. Works councils in Croatia also have certain rights that go beyond the usual rights of local trade union representatives (Kohl, 1998). 
In practice, works councils currently play a fairly important role in Croatia, a less substantial one in Bosnia - with, to date, around 300 works councils - and, thus far in Serbia, a fairly marginal one. Here, too, more detailed provisions on the functioning of works councils are due to be set out in a special law that has not yet come into existence. After its separation from Serbia in 2006, Montenegro has, in any case, abandoned the possibility of establishing works councils that previously existed under the 2003 Labour Law. This possibility is no longer included in the new Labour Law of autumn 2008.

In Macedonia, by contrast, where there is currently one single system of employee representation, i.e. via local trade union representatives, the possibility of introducing works councils is under discussion and is supported by some unions. In Albania, the legislative created, in 2008, the possibility of forming an employee representation body with a range of different rights of information in companies having twenty or more employees (ITUC, 2009).

Furthermore, trade unions in this region - with the exception of those in Croatia tend on the whole to take a sceptical view of the institution of works councils. They fear that they would be unwelcome competition, or even undermine their own existence, although experience invariably shows that, if works councils were to be used effectively, unions would, on the contrary, be likely to benefit from more extensive employee participation rights, closer co-operation and, above all, redoubled recruitment opportunities. In addition, it can be assumed that the workers councils of the former Yugoslavia operated rather differently and with different effects, with the result that, during the transformation period, public opinion often wrongly held the past self-management system partly responsible for the failure of Titoist socialism.

From a legal point of view, the countries with provision for works councils have complied with the minimum conditions for applying the 2002 EU directive on information and consultation, but the content of the legislation in question and its implementation differs from one country to another. ${ }^{2}$

To summarise the institutional context, the following picture emerges of the intensity and quality of employee representation in the region, based on the estimates and findings of observers:

- if we take the total proportion of employees in a country who are represented by a company trade union and by a works council as well, then in Macedonia, Albania and Serbia this figure is little higher than the percentage of employees organised in a trade union (the lower figure for Serbia is the result of less adequate representation in the private sector)

- on the other hand, the proportion of employees represented in Croatia and Bosnia is higher, due to more widespread works councils and a strong union presence in medium-sized and large enterprises

- a similarly high percentage to Bosnia and Croatia is reported for Montenegro which suggests that company union representation is relatively more widespread. Nevertheless, it is doubtful whether this is true of the many small and micro-en-

2 For further details, see the complete version of the study on freedom of association by Kohl (2009). 
terprises newly established in the wave of privatisation in a country where $74 \%$ of companies are in the service sector: this subject merits further study.

Moreover, the primary focus of company trade unions is invariably the conclusion of collective agreements. Such outcomes therefore also provide reliable information on the number of employees in that country who fall within the scope of the unions.

\section{Collective bargaining practice and workforce coverage}

The collective bargaining landscape in the western Balkans is largely dominated by company agreements. In addition, sectoral agreements are found to varying degrees in certain countries in both public and private sectors, resulting in correspondingly higher rates of coverage. This is particularly the case where these agreements can be made generally binding on all employers in a sector, and this will be considered in detail below.

Generally speaking, there are also tripartite framework regulations agreed between the competent ministries and the social partners that then serve as framework collective agreements for all employees in the public or private sector. However, as a rule they contain little more in terms of substance than the statutory minimum standards that apply anyway, plus a number of other elements relating to bonuses, meal allowances, redundancy pay and provisions on working time and annual leave. They do not contain specific pay scales but, at best, do include provisions on a minimum wage that may be generally applicable or otherwise further specified within the sector. In this context, the government is, in any case, frequently less interested in genuine social dialogue than in achieving its political objectives and, what is more, is subject to conditions set out by the international financial institutions (see Friedrich-Ebert-Stiftung, 2009a).

Such tripartite framework agreements involving the government are found in both entities of $\mathrm{BiH}$, in Macedonia and in Montenegro and generally apply to all relevant employees in the public and private sectors. It would be a mistake, however, to view this as tantamount to the complete coverage of all employees, since in Macedonia and Montenegro, for example, a statutory minimum wage has yet to be introduced. In Kosovo, the tripartite collective agreement, concluded in 2004, has not been implemented as yet - primarily for financial reasons - as argued by private employers as well as by the government.

At sectoral level, there has recently been an increasing number of agreements in certain countries. They cover:

- primarily the public sector in Serbia and both parts of $\mathrm{BiH}$, and broad sections of the public service, public utilities and service sectors in Macedonia and Albania

- however, in the private sector there are now also more sectoral agreements (though with distinct gaps in coverage) in Croatia (17), Montenegro (17) and Macedonia (16 - of which several are recent). To date, there have been fewer in Bosnia-Herzegovina. 
On the other hand, collective agreements at company level continue to predominate:

- in the Serbian private sector (provided the company trade union represents at least $15 \%$ of the workforce)

- widely in Croatia, but frequently in the form of agreements that supplement sectoral agreements

- and also in Albania.

- In Kosovo, the Chamber of Commerce, as the so-called social partner of the trade unions, shows little interest in collective bargaining. Pay setting thus depends mainly on the respective employer, i.e. on the structural conditions of the labour market (see below).

In addition, there is the possibility of achieving broader coverage where the competent ministry declares a collective agreement to be generally applicable. In Croatia, this is currently true of six sectoral agreements (in tourism, hotel and catering, commerce, construction, the timber industry and SMEs in the craft sector). This means that all employers in these sectors are bound by the provisions of the existing agreements irrespective of their membership of an employer association. Similarly, collective agreements covering six public sector industries in Serbia have been declared generally binding and thus apply nationwide.

In theory, this instrument could also be introduced in Albania in circumstances where a sectoral agreement covers more than $50 \%$ of the workforce in question. In Macedonia, however, this is not a legal possibility up to now.

The coverage of employees by any collective agreement (national, sectoral or company level) in the region may be described as indicated in Figure 5.

Across the region as a whole, binding agreements have so far had a relatively minor impact in practice, despite the wider coverage of some national framework agreements, as is commonplace in Montenegro and Bosnia, but even those do not set wage levels (wage grids). Such coverage tends to be more significant in Croatia, with its numerous company and sectoral agreements. In this country, too, a statutory minimum wage was first introduced in 2008 to replace the existing minimum wage established by national collective agreement. 
Figure 5 - Overall proportion of employees covered by collective agreements

70

60

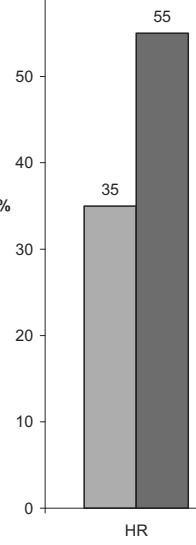

55

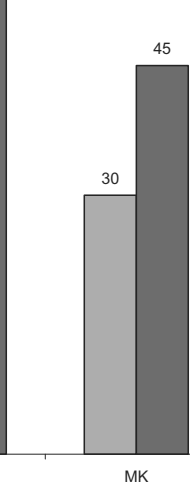

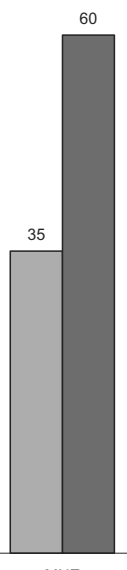

MNE

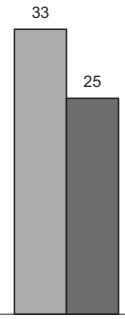

SRB

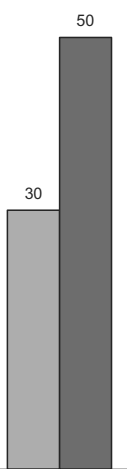

$\mathrm{BIH}$

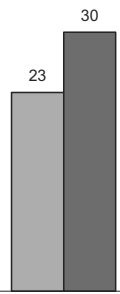

$\mathrm{AL}$

¿Union density $\square$ Collective bargaining coverage

\section{The right to strike: legal prescriptions and practice}

The right to strike, like freedom of association, is guaranteed in principle in all countries of the region by the constitution and/or specific legislation. In practice, however, it is also restricted by a range of administrative provisions. Certain groups of employees are totally prohibited from taking strike action.

This situation stems from the fears - largely apparent at the beginning of the transformation period - that public order might be jeopardised by uncontrollable waves of strike action, that supplies might no longer be guaranteed and that all this might deter foreign investors. In fact, none of this occurred: indeed, with a few exceptions, the desire for industrial action has now subsided almost completely. What is more, employers in three of the six countries now have the right to undertake lock-outs. action:

The following groups of employees are restricted as regards taking part in industrial

- members of public services may only take limited strike action; they may not do so at all in Albania; and, in Croatia, participation is subject to certain restrictions

- employees in so-called 'essential services' (utilities, public security, etc.) are also prohibited from strike action in Serbia and Albania

- in Republika Srpska (BiH), public sector production must not be interrupted

- on the other hand, Macedonia has no fundamental restrictions in this respect - even members of the army may take strike action once a year. 
Administrative requirements mainly consist of the duty to provide specific notice of strike action. They stipulate for:

- Serbia: notice to be given to the employer at least fifteen days before the start of strike action

- Montenegro: usually a notice period of five days but ten days in 'essential' services

- $\mathrm{BiH}$, in the Bosniak-Croat Federation: generally ten days; in Republika Srpska: eight days before the start of strike action.

In virtually all cases, a strike is only legally permissible as a last resort, in a pay or other industrial dispute, after compulsory conciliation or arbitration, or prior voluntary mediation, again with specific and sometimes extended cooling-off periods. These rules are designed to help the parties arrive at a compromise, as well as offering the necessary opportunities for a calming down during a heated dispute. Failing to abide by these can see a work stoppage declared illegal by the courts, which can result in serious demands for compensation or other disciplinary measures affecting the workforce and, in particular, the organisers of the strike.

In $\mathrm{BiH}$, an employer is legally permitted to lock out up to half of any striking workers and the same goes for Croatia. In Macedonia, however, this is much more limited, at up to $2 \%$ of strikers. To date, this legal possibility has not been used in practice: it arose largely from the principle of formal parity.

All of this - along with the general economic and labour market situation, on top of widespread migration - means that today there are virtually no widespread strikes in south-eastern Europe, with a few exceptions involving certain public sector professions. At the very most, strikes occur in individual larger companies and are triggered by breaches of collective agreements or unjustified wage arrears. Strikes therefore tend to be viewed as a means of resistance rather than as an active tool in the struggle for a fair income distribution. In Kosovo, no strike actions have been reported in recent years - apart from some demonstrations by teachers in 2009.

\section{The role of minimum wages}

The tangible impact of social dialogue and of the specific approach to bargaining in the western Balkans can be evaluated using a range of significant indicators and parameters. Most telling of these are minimum and average wages in a country, when viewed against the relevant macroeconomic data. Compared with the new eastern European member states, however, there is less data available for the western Balkans, since Eurostat does not yet carry out continuous or systematic monitoring of these countries, with the exception of the candidate states of Croatia and Macedonia. Moreover, certain macroeconomic parameters, such as productivity, cannot always be measured and reported on a comparable basis. To take this example, those involved in the bargaining process are themselves frequently not as well-informed as they should be about such data, as is evident from simulated planning exercises carried out at sectoral level in the context of EU projects. In addition, a focus on the situation in individual companies and company agreements in any case creates a different approach, geared primarily towards microeconomic data. 
A comparison of the key macroeconomic parameters across the countries of the region may serve as an indication of the outcomes of income distribution policy (Table 2).

\section{Table 2 - Minimum wages in $€$ and as a proportion of the average wage in} south-eastern Europe (\%) - 2008

\begin{tabular}{|l|c|c|c|c|c|c|c|}
\hline & HR & MK & MNE & SRB & BiH & AL & KS \\
\hline Minimum wage & 381 & $\begin{array}{c}(75-218 \\
)^{1}\end{array}$ & $(55)$ & 159 & $159 / 142^{*}$ & 138 & $(120)$ \\
\hline Average wage & 1000 & 250 & 630 & 400 & $514 / 452^{*}$ & 350 & 250 \\
\hline $\begin{array}{l}\text { Minimum wage as \% of } \\
\text { average wage }\end{array}$ & 38 & $(30)$ & $?$ & 39 & 31 & 41 & $(45)$ \\
\hline Growth in GDP (\%) & 2.4 & 5.0 & 8.1 & 5.4 & 5.5 & 7.2 & 5.0 \\
\hline Unemployment (\%) & 13.4 & 33.8 & 10.8 & 18.8 & 40.6 & $\begin{array}{c}\text { approx. } \\
33^{2}\end{array}$ & $45^{3}$ \\
\hline
\end{tabular}

* Figures for Republika Srpska

${ }^{1}$ Lowest wage bracket as per collective agreement in the textile industry and the health sector in 2008

${ }^{2}$ With an official rate of $13 \%$, actual unemployment is estimated to be 30-35\%; however, due to the high proportion of informal employment, this real figure is not registered (as in $\mathrm{BiH}$ and $\mathrm{MK}$ )

${ }^{3}$ Official data-estimates of real unemployment report a level of 60-70\% (due to the widespread informal economy).

What is initially most striking here is that three of the seven countries do not have a statutory minimum wage.

In Macedonia, the minimum figure is based merely on the lowest wage bracket where specified in a sectoral agreement. The range cited in Table 2 is from the lowest wage, equivalent to $€ 68-75$ in the textile and leather industry, to current monthly earnings (in 2008/2009) of around $€ 218$ in the health professions. The threshold for the payment of social security contributions, etc. is $€ 166$, or $65 \%$ of the average wage in the country. In reality, the lowest income is likely to be significantly lower than this threshold.

Montenegro similarly has no statutory minimum wage. The figure quoted in brackets in Table 2 of $€ 55$ merely represents the minimum amount on the basis of which an employer is required to pay social security contributions at the nationally applicable rate (where necessary, also for part-time workers). Compared to an average income in the country of $€ 600$, this is a very low figure. It is no surprise, therefore, that trade unions and others have long been calling for a minimum wage in Montenegro. An initial step in this respect, involving the national tripartite Social Council established in mid-2008, took the form of an amendment to the Montenegrin Labour Law in Sep- 
tember 2008, setting out in detail the economic parameters that agreements must take into account.

Furthermore, it was not until July 2008 that Croatia first enshrined a national minimum wage in law, following years of internal debate. This was after it became evident that the existing minimum wage - previously fixed by national bilateral agreement between the social partners - could no longer be adjusted and was far from sufficient to guarantee a decent livelihood for full-time employees.

Similar to the situation in central eastern Europe, the minimum wage as a proportion of the average wage in the countries of the western Balkans ranges between only $30 \%$ and $40 \%$. Decisions in this respect are generally taken by the government in consultation or agreement with the particular national Economic and Social Council, so such figures tell us much about the overall quality of tripartite social dialogue in a particular country.

In Kosovo, the minimum wage level foreseen by the tripartite collective agreement signed in 2004 has not so far been implemented, or even adapted in the past years. It serves as a certain orientation for salaries in the civil service, whereas in the private sector the lowest wages start at some $€ 200$ per month.

\section{Tripartite social concertation}

The recent progress reports by the EU Commission, of November 2008 and of October 2009 , provided a critical assessment of the state of social dialogue at this level in the individual countries of the western Balkans, as set out in Table 3:

\section{Table 3 - Effectiveness of national social dialogue in south-eastern Europe (from} an EU perspective)

\begin{tabular}{|l|l|l|}
\hline Croatia & $\begin{array}{l}\text { Economic and Social } \\
\text { Council (re-established } \\
1999)\end{array}$ & $\begin{array}{l}\text { 'Tripartite social dialogue is already well } \\
\text { established... has resulted in the Act on minimum } \\
\text { wage' (2008) }\end{array}$ \\
\hline Macedonia & $\begin{array}{l}\text { Economic and Social } \\
\text { Committee (established } \\
1995)\end{array}$ & $\begin{array}{l}\text { 'The Economic and Social Committee does not } \\
\text { fulfil its role... Until the labour law is amended } \\
\text { accordingly, it not possible to ensure a functional } \\
\text { social dialogue.' }\end{array}$ \\
\hline Montenegro & $\begin{array}{l}\text { National Social Council } \\
\text { (since mid-2008) }\end{array}$ & $\begin{array}{l}\text { 'Some progress has been made in social } \\
\text { dialogue... A Social Council was established in } \\
\text { June 2008' }\end{array}$ \\
\hline Serbia & $\begin{array}{l}\text { Socio-Economic } \\
\text { Council } \\
\text { (established 2005) }\end{array}$ & $\begin{array}{l}\text { 'Social dialogue is still weak. The role and capacity } \\
\text { of the Socio-Economic Council still need to be } \\
\text { fully developed.' }\end{array}$ \\
\hline $\begin{array}{l}\text { Bosnia- } \\
\text { Herzegovina }\end{array}$ & $\begin{array}{l}\text { No country-wide } \\
\text { economic and social } \\
\text { council; exists only at } \\
\text { entity levels }\end{array}$ & $\begin{array}{l}\text { 'No development in establishing the trade union } \\
\text { confederation (KSBH)... No country-wide } \\
\text { economic and social council has been established.' }\end{array}$ \\
\hline Albania & $\begin{array}{l}\text { National Labour } \\
\text { Council (established } \\
1996)\end{array}$ & $\begin{array}{l}\text { 'The absence of a revised labour law is hampering } \\
\text { the transformation of the National Labour Council } \\
\text { into a National Social and Economic Council.' }\end{array}$ \\
\hline
\end{tabular}




\begin{tabular}{|l|l|l|}
\hline Kosovo & $\begin{array}{l}\text { Tripartite Advisory } \\
\text { Council (set up in 2001) }\end{array}$ & $\begin{array}{l}\text { 'Very limited progress can be reported in the area } \\
\text { of social dialogue... The Tripartite Advisory } \\
\text { Council is not operational.' }\end{array}$ \\
\hline
\end{tabular}

Quotations: EU Progress Report of 8 November 2008

The new Progress Report from October 2009 (EC 2009b) again attests as regards Croatia that the:

Tripartite social dialogue continues to be relatively well-developed,

whereas, in all other countries of the western Balkans, the deficits in social concertation in influencing the decision-making processes of the government are again repeated in a similar manner. For Kosovo too, the recent report sees only 'minimal progress' in the area of social dialogue:

The Tripartite Advisory Board has been renamed the Socio-Economic Council and met in July... The collective agreement signed in 2004 on the minimum wage is not implemented.

This repeated contrasting positive image concerning Croatia is obviously the result of a longer-lasting tradition of national tripartite social dialogue, as well as of the established practice of the numerous bipartite agreements at national and sectoral level which operate in this country.

On the other hand, over the past few years the countries of the western Balkans have experienced extremely dynamic annual economic growth rates of between $6 \%$ and $10 \%$. This has now fallen considerably due to the global crisis, but in individual countries is likely to remain in positive figures - even in Kosovo. However, it is apparently only Croatia and Montenegro - thanks above all to their tourist booms - that have succeeded in passing on a sufficient proportion of their increases in productivity to employees. What is significant here is the type of agreement that predominates and the proportion of those covered by such an agreement (see Figure 5 above).

Invariably in this context, the level of employment and the actual unemployment rate in a country also have a decisive importance as regards income distribution policies. Macedonia, $\mathrm{BiH}$ and Albania each have an actual level of unemployment of well over $30 \%$, while for the remaining countries it is between $15 \%$ and $20 \%$. To some extent, this hampers the ability of trade unions to assert their demands and thus limits the success of an income distribution policy. Furthermore, all these three countries have a large proportion of people working in the informal sector. This is a special problem also for Kosovo, where the official data report unemployment at $45 \%$ but, in reality, this proportion seems to be more than $50 \%$, linked to the high degree of migration of Kosovars.

In light of this situation, there are large contingents of the working population in south-east European countries working abroad. It is true that such migration reduces unemployment and strengthens the national economy, with the regular transfer back home of large sums earned abroad. Moreover, where migration has already caused a 
lack of skilled labour, and hence bottlenecks in certain sectors of the labour market, it can also lead to a more active income distribution policy. This is apparent from comparable developments regarding the minimum wage in Romania and the Baltic States over the last few years. However, in the current world economic crisis, the impact of this trend diminishes the more migrant workers lose their jobs and are the first to return home when jobs are cut.

A further consequence of the approach taken to bargaining is the extent of the pay gap between employees in a given country. It was reiterated in the latest EU Commission Report on Industrial Relations in Europe 2008 that there is a clear connection between a country's union density and collective bargaining/agreement structures on the one hand and, on the other, the measurable pay inequalities between the highest and lowest earners, as well as between men and women. Wage differentials in the former socialist countries of eastern Europe are generally much more pronounced in absolute terms than in western Europe, although this is less true of countries with widespread sectoral agreements and larger trade union membership in both east and west.

Consequently, the countries of the western Balkans - with the exception of Croatia - also show greater inequalities in income distribution. This is evident from the simple arithmetic that, where the minimum wage of a country represents a low percentage of average income, there must be a correspondingly large proportion of people with incomes that are several times higher and which therefore inflate the average wage quite apart from the practice of cash-in-hand payments (i.e. undeclared pay) that is also widespread in this region. Where pay policy is only regulated by agreement to a limited degree or hardly at all, skilled employees invariably earn disproportionately more than those in less skilled and more common jobs than when the reverse is true (cf. EC, 2009a Part 3).

\section{Control of implementation of employee and trade union rights}

The quality of labour rights and standards depends, firstly, on the codified legal provisions; and, secondly, on how social dialogue works in practice. Another crucial factor, however, is the question of how agreements made within the social dialogue or under existing legislation are implemented on the ground. Monitoring of this requires the relevant players and authorities to be robust and equipped with sufficient powers of enforcement.

Once again, there are clear differences in this respect within the western Balkans. Where it has been possible to achieve a high density of agreements and a high degree of regulation, the relevant standards are higher than in areas where this is not the case. Shortcomings are particularly apparent where statutory monitoring and controls cannot impose corrective sanctions or act as a deterrent. We saw previously in other sections that clear differences are apparent between the labour standards implemented in EU accession candidate Croatia and those in its neighbours in the western Balkans.

Apart from the question of their legal basis in specific laws and regulations, the labour standards compared here primarily stipulate the following five areas: 
- as far as possible, the existence of systems of employee representation with guaranteed powers in all sizes of company

- comparable working conditions and remuneration for comparable work, guaranteed by effective collective agreements

- intervention by dispute settlement bodies on issues pertaining to collective labour rights (particularly bargaining policy and the exercise of the right to strike)

- a labour inspectorate that works effectively

- judicial monitoring and protection for individual and collective labour rights in the event of obvious infringements.

Quite apart from the gaps in the legislation and in the implementing regulations, the focus at this juncture is particularly on the implementation, promotion and monitoring of existing legislation.

In the countries studied, some dispute settlement bodies have recently been extended to include, alongside arbitration, voluntary mediation (advice) and conciliation services (mediation and help in reaching a compromise solution) before a dispute escalates into possible industrial or legal action. However, this kind of conflict resolution is still in its infancy as such services are, as yet, seldom used.

In general terms, the role of these new bodies is to carry out compulsory arbitration during pay disputes. In Serbia in 2005, a public 'Agency for the Settlement of Industrial Disputes' was set up specifically for this purpose. In Montenegro, there is similarly a provision in the law for compulsory mediation and arbitration in disputes in sectors 'of public interest', although not for the private sector. In Albania, too, there are state mediation and dispute settlement agencies that must be called upon prior to taking possible industrial action. This situation is similar in Macedonia and Croatia.

It is an open question, however, as regards the extent to which such bodies can be - or actually are - called upon to help interpret the disputed aspects of collective agreements and whether they can operate effectively in such cases.

In this region, arbitration is a function traditionally performed by the labour inspectorate, provided it has the requisite monitoring and decision-making powers. This is the case in Serbia, where this body is reported to have comprehensive rights, including the power to remedy rights violations (including illegal dismissal). In such cases, however, the effectiveness of any possible sanctions is always questionable. The labour inspectorate in Montenegro possesses similar broad powers to monitor labour law and health and safety in the workplace. It is, moreover, equipped with sufficient staff resource to enable it to carry out the regular monitoring of individual companies at relatively short intervals.

The issue of staff resources is problematic in Croatia since, according to the trade union confederation SSSH, $50 \%$ of posts in the labour inspectorate are currently vacant. In Macedonia, according to the EU Progress Report 2008, personnel have been increased by $30 \%$ (from 96 to 129 posts); however, the trade unions consider that the inspectorate has relatively little power to impose penalties.

In Bosnia-Herzegovina the labour inspectorate also has wide-ranging powers to monitor the implementation of legislation and collective agreements. A new draft law provides even for the possibility of halting production in the event of serious breaches of health and safety regulations. The inspectorate also has powers to monitor the im- 
plementation of dismissal protection regulations: for such activities, the inspectorate provides intensive training for its own personnel as well as for a number of employee representatives.

The Labour Inspection Authority was introduced in 2002 in Kosovo but, despite legal enforcement in 2008, no effective sanctions can be executed as long as a functioning labour code is missing.

The issue of court action for the violation of labour rights, whether individual or collective, is a particularly thorny one.

The labour courts that existed in the former Yugoslavia are not found in any of the successor states or in Albania, even though they are clearly required given that court cases take far too long and that the civil courts lack the competence to deal with labour disputes. This is why the trade unions have also incessantly demanded them. In Albania, the introduction of labour courts was provided for some time ago in the 2003 Labour Code but this has still not yet been implemented in practice.

Nevertheless, this region still has specific departments, or labour law chambers, as has been established for example within the system of ordinary courts in Macedonia and Serbia. However, this has not brought about any noticeable reduction in the duration of court proceedings, which usually take as long as two or three years.

Finally, the enforcement of court judgments constitutes a particular problem. There have been repeated complaints about dismissals, for example of trade union activists, that have been declared illegal but which are subsequently not rescinded by the company responsible and with no reinstatement of the employees in question. Reports from Croatia state that around one-third of judgments are not enforced, since the companies accused either no longer legally exist or else prefer to pay the corresponding fine as an alternative. This again raises the crucial issue of an effective system of penalties for breaches of the law that could have the power to deter.

\section{Necessity of social dialogue and transnational co-operation}

Following this analysis of the salient features of industrial relations in the western Balkans, an initial appraisal leads us to the following conclusions:

- in terms of indicators, the situation in Croatia is more close to the situation in the more developed new EU member states. It already largely meets the industrial relations standards usual in the EU. This means that, alongside Slovenia, it is the only former Yugoslav country in the region in which the previous tradition of worker self-management has remained alive. This is evident from the decision to introduce works councils (as early as 1995) and from the presence of employee representatives on supervisory boards of companies with 200 employees and over

- nonetheless, in terms of their structures, the remaining countries of south-eastern Europe are not lagging behind the new EU member states to any considerable extent - indeed, with regard to essential indicators such as collective agreement coverage and union density, the opposite is generally the case. Their economic performance and income levels are in the same range as those of the two member states of the eastern Balkans, Bulgaria and Romania, which joined the EU in 2007. The result 
of the initial delay in embarking on the transformation process is that they need

time for the continuing further development of the social dialogue.

In the current and potential accession states in the western Balkans, projects financed by the European Social Fund (ESF) to promote social dialogue should, therefore, come more into the focus of trade union activities. These call for concrete initiatives in collaboration with the national social partners and the governments concerned. The same applies to pre-accession projects financed under the European Union IPA programmes (Instruments of Pre-Accession Assistance) since 2007. ${ }^{3}$

Already struggling to defend themselves, to stem the loss of members and to cope with the challenges of the global crisis, the trade union organisations of south-eastern Europe are in no position to achieve this on their own. The social dimension in an enlarging European Union has the chance to succeed only where it is accompanied by the intensified transnational co-operation, exchange of experiences and transfer of knowledge of all the trade union organisations and actors involved in social dialogue.

\section{References}

Carley, M (2009) Trade union membership 2003-2008 EU Foundation: Dublin http:// www.eurofound.europa.eu/eiro/studies/tn0904019s/tn0904019s.htm

Đurić, D (2003) Social Dialogue, Tripartism and Social Partnership Development in the South East European Countries, Including Recommendations for Serbia and Montenegro (with case studies of Croatia and Montenegro) http://pdc.ceu.hu/archive/00001829/01/Djuric.pdf

EC (2009a) Industrial Relations in Europe 2008 Luxembourg http://ec.europa.eu/social/main.jsp?catId=575\&langId=en

EC (2009b) Progress Reports concerning the candidate countries Croatia and Macedonia and the potential candidates (Albania, BiH, Montenegro, Serbia, Kosovo) from 14 October 2009

http://ec.europa.eu/enlargement/press_corner/key-documents/reports_oct_2009_en.htm

ECFIN (2009) EU Candidate and Pre-accession Countries Economic Quarterly (Unit D-1 - quarterly issues) most recent:

http://ec.europa.eu/economy_finance/publications/publication15969_en.pdf

Friedrich-Ebert-Stiftung (2009a) Aktuelle Informationen aus Süd-Ost-Europa: Schwäche der Sozialpartnerorganisationen zeigt sich in ihrer Zersplitterung (Länderübersichten über Sozialpartner-Organisationen) Belgrade, March 2009 www.fessozialdialog-soe.de

3 For more about the mechanisms of the IPA, see EC (2009) A new focus to EU assistance for enlargement http://ec.europa.eu/enlargement/pdf/publication/ipa_brochure_2009_en.pdf and concrete projects in the south-east Europe region: http://ec.europa.eu/regional_policy/funds/ipa/ index_en.htm. 
Friedrich-Ebert-Stiftung (2009b) Sozialer Zusammenhalt in Bosnien und Herzegowina (also in Croatia: Socialno povjerenje u BiH) Sarajevo (author: B. Šalaj) http://library.fes.de/pdf-files/bueros/sarajevo/06159.pdf

Hethy, L (2002) 'Labour law for Kosovo' South East Europe Review for Labour and Social Affairs 5(3): 65-77.

Hoti, A. (2005), A Background Study on Labour Relations in Kosova, University of Prishtina (Faculty of Economy - online available)

ITUC (2008 and 2009) Annual survey of violations of trade union rights for 2008: http:// survey08.ituc-csi.org; for 2009: http://survey09.ituc-csi.org

Kohl, H (1998) Prava zaposlenika - zaposleničko vijece - sindikat (Arbeitnehmerrechte - Betriebsrat - Gewerkschaft-Auswertung deutscher und kroatischer Erfahrungen) Zagreb: FES

http://library.fes.de/pdf-files/bueros/vifaost/a98-10794.pdf

Kohl, H (2009) Freedom of association, employees' rights and social dialogue in Central and Eastern Europe and the Western Balkans (edited by Friedrich-Ebert-Stiftung, Hans-Böckler-Stiftung, Otto Brenner Stiftung and the European Trade Union Institute) Berlin http://library.fes.de/pdf-files/id/06606.pdf

Short versions also in Bosnian-Croatian-Serbian, Bulgarian, Polish, Czech and Hungarian are available online; versions in Albanian and Romanian are in preparation.

Konjufca, G and V. Murati (2008) Economic and Social Rights: Labour Rights in the Kosova Context Friedrich-Ebert-Stiftung Prishtina Office and the Human Rights Centre of the University of Prishtina.

Wannöffel, M, J. Le and J. Kramer (2007) 'Industrial relations structures in south-east Europe and Turkey: a view from the metalworking industry' South-East Europe Review 10(3): 7-40.

\section{Appendix: National trade union confederations in south-east Europe}

(with year of foundation ( $\mathrm{N}=$ newly founded; former state organisations)

Albania

KSSH: $\quad$ Confederation of Trade Unions of Albania (N; 1991)

BSPSH: $\quad$ Union of Trade Unions of Albanian Workers (1991)

FSTBFH: $\quad$ Federation of Trade Unions of Albania (1997)

$\mathrm{BiH}$

CTUBiH: $\quad$ Confederation of Trade Unions of Bosnia and Herzegovina (2004)

SSSBiH*: $\quad$ Confederation of Independent Trade Unions of Bosnia and Herzegovina (1905)

SSRS*: $\quad$ Confederation of Trade Unions of the Republika Srpska (1992)

*limited to each 'entity' (Bosnian-Croatian Federation or RS)

Croatia

SSSH: $\quad$ Union of Autonomous Trade Unions of Croatia (N 1990)

NHS: $\quad$ Independent Trade Unions of Croatia (1999) 
Matica: $\quad$ Association of Croatian Public Sector Unions (1993) - merged in 2008 with Uni-

HUS: $\quad$ Croatian Association of Trade Unions (1990)

URSH: $\quad$ Workers Trade Union Association of Croatia (1994)

Kosovo

BSPK:

KLSK:

Union of Independent Trade Unions of Kosova (1990)

Confederation of Free Trade Unions in Kosova (2007)

Macedonia

SSM:

KSS:

Federation of Trade Unions of Macedonia (N; 1989)

Federation of Free Trade Unions of Macedonia (2005)

Montenegro

SSSCG: $\quad$ Confederation of Trade Unions of Montenegro (N; 1991)

Serbia

SSSS:

UGS:

Independent Confederation of Trade Unions of Serbia (1903)

Nezavisnost - 'Independence' Trade Union Confederation (1991) 